\title{
PEMBENTUKAN LMDH: UPAYA MENCEGAH KONFLIK ANTARA PERUM PERHUTANI DAN MASYARAKAT SEKITAR HUTAN
}

\author{
Wartiningsih \\ Nunuk Nuswardani \\ Fakultas Hukum Universitas Trunojoyo Madura \\ Kampus Unijoyo, Telang, PO. BOX 2 Kamal - Bangkalan \\ Email: wang_0262@yahoo.co.id
}

\begin{abstract}
This service activities Proposer Team begins concerns over the proliferation of various conflicts, looting and "resistance" of forest communities against Perum Perhutani KPH Madura. Whereas the existence of KPH as an institution at the site level / field has tasks and functions that are strategic security, protection, management of forest products, strengthening of public institutions, as well as the conflict resolver. Based on the identification and justification of existing problems, these service activities using the methods of implementation in the form of socialization, FGD and interviews. At the end of service activities can: (1) Establishment of Forest Village Community Organization (LMDH) in the framework of forest resources management system Collaborative Forest Management (CBFM); (2) To encourage and help people to register the certificate of its Land Rights; (3) For the realization of these service activities, Tim Proposer help citizens to obtain permits utilization of forest land from Perhutani KPH Madura as State forest managers.
\end{abstract}

Key words: people around the forest, LMDH, perhutani, PHBM

\begin{abstract}
Abstrak
Kegiatan pengabdian ini diawali keprihatinan Tim Pengusul atas maraknya berbagai konflik, penjarahan dan "perlawanan" masyarakat sekitar hutan terhadap Perum Perhutani KPH Madura. Padahal keberadaan KPH sebagai institusi di tingkat tapak/lapangan memiliki tugas dan fungsi yang strategis yaitu pengamanan, perlindungan, manajemen pengelolaan hasil hutan, penguatan kelembagaan masyarakat, sekaligus sebagai penyelesai konflik. Berdasarkan identifikasi dan justifikasi permasalahan yang ada, kegiatan pengabdian ini menggunakan metode pelaksanaan berupa sosialisasi, FGD dan wawancara. Pada akhir kegiatan pengabdian ini dapat: (1) Terbentuknya Lembaga Masyarakat Desa Hutan (LMDH) dalam rangka pengelolaan sumber daya hutan dengan sistem Pengelolaan Hutan Bersama Masyarakat (PHBM); (2) Mendorong dan membantu masyarakat untuk mendaftarkan sertifikat Hak atas Tanah yang dimilikinya; (3) Sebagai realisasi dari kegiatan pengabdian ini, Tim Pengusul membantu warga untuk mendapatkan surat ijin pemanfaatan tanah kawasan hutan dari Perum Perhutani KPH Madura selaku pengelola hutan Negara.
\end{abstract}

Kata kunci: masyarakat sekitar hutan, LMDH, perhutani, PHBM 


\section{Latar Belakang}

Berkaitan dengan dengan arah pembangunan jangka panjang Kabupaten Bangkalan, kebijakan tata ruang merupakan bagian integral dari kebijaksanaan umum dan sektoral yang telah ditetapkan. Dalam kerangka ini, untuk penyebarluasan kegiatan pembangunan di seluruh wilayah Kabupaten Bangkalan, maka ditetapkan Sub Satuan Wilayah Pengembangan (SSWP). Sesuai dengan konsep dan strategi penataan ruang, maka sistem perwilayahan di Kabupaten Bangkalan dibagi menjadi 6(enam) Sub Satuan Wilayah Pengembangan (SSWP). Masingmasing pusat SSWP akan memiliki fungsi dan peran sesuai dengan potensi yang dimilikinya. Kecamatan Modung sebagai SSWP IV. SSWP IV sebagai pusat pertumbuhan dengan fungsi kegiatan: pertanian, peternakan, perkebunan, industri kecil, perdagangan skala lokal.

Namun, sudah sejak lama hingga saat ini ada permasalahan antara pihak Perum Perhutani KPH Madura dengan masyarakat desa Patengteng yang tidak kunjung usai, berkaitan dengan klaim kepemilikan tanah masyarakat yang berdekatan dengan kawasan hutan negara.

Kegiatan pengabdian ini memiliki 2 (dua) mitra, Mitra I adalah Perum Perhutani KPH Madura dan Mitra II masyarakat sekitar hutan di dusun Bulak desa Patengteng Kecamatan Modung Kabupaten Bangkalan. Sengketa antara Mitra I dan Mitra II sudah berlangsung lama yang tidak kunjung selesai.
Permasalahan bersumber dari kepemilikan dua dokumen pertanahan (milik Perhutani dan milik warga Desa Patengteng) yang samasama dianggap memliki kebenaran oleh kedua belah pihak. Pihak Kepolisian Sektor (Polsek) Modung telahmengupayakan pertemuan untuk menjembatani pihak yang bersengketa agar permasalahan yang terjadi dapat diselesaikan dengan baik. Namun, sangat disayangkan pihak Perum Perhutani tidak menghadiri undangan itu dengan berbagai macam alasan, sehingga menyebabkan kekecewaan dari pihak kepolisian dan masyarakat setempat. Pertemuan ini digagas Kapolsek Modung untuk memberi penyadaran kepada pihak perhutani bahwa tanah tersebut adalah tanah sengketa, akan tetapi pihak Perhutani menganggap lahan tersebut bukan tanah sengketa.

Sengketa berkepanjangan tersebut berlanjut sampai di DPRD Kabupaten Bangkalan. Anggota Komisi A DPRD Bangkalan, Mujiburahman menyatakan, untuk mengatasi permasalahan ini harus dilakukan uji kebenaran atas bukti yang dimiliki oleh pihak Perum Perhutani. Sebab, masyarakat mengatakan tanah tersebut adalah tanah milik nenek moyang dengan bukti sertifikat leter C. Sampai saat ini pihak Perum Perhutani tidak pernah memberikan bukti kepada DPRD, meski bukti itu sudah diminta dengan melayangkan surat permohonan.

Hutan yang ada di sebagian wilayah Kecamatan Modung termasuk kedalam Kelompok Hutan Madura Daratan yang 
pembagiannya menjadi Bagian Hutan Madura Barat seluas: 3.999,40 Ha. Tanah hutan yang diklaim milik warga Dusun Bulak, Desa Patengteng mulai ada titik terang pada tanggal 1 Februari 2014, setelah ada keterangan dari pihak Perum Perhutani kepada Polres BangkalanbahwaberdasarkanSuratKeputusan Menteri Kehutanan RI, dengan nomor 26/kptsII-1987, hutan gunung yang disengketakan tersebut telah ditetapkan sebagai kawasan hutan. Berdasarkan informasi dari pihak Perum Perhutani menyebutkan, bahwa kawasan hutan tersebut pengelolaannya diserahkan kepada Bagian Kesatuan Pemangkuan Hutan (BKPH) Madura Wilayah Madura Barat, dalam hal ini Perum Perhutani.

Penjelasan Asisten Perhutani (Asper), Rifa'i pada pra-penelitian menyatakan,bahwa kawasan hutan yang diklaim milik warga tersebut berdasarkan SK Menteri Kehutanan, pengelolaannya ada pada perhutani. Berdasarkan SK (SK Menhut tersebut), di Madura Barat yang masih kawasan hutan di antaranya, Gunung Lombang Daja, Gunung Patengteng Srabi,Gunung Manggaan Sanjangan dll. itu ditetapkan sebagai kawasan hutan, dengan luas 3.137. $75 \mathrm{Ha}$.

Asper Rifa'i menambahkan, pihak Perum Perhutani tidak akan mengelola kawasan tersebut kalau tidak punya peta dan data. Permasalahan muncul karena terhadap tanah-tanah tertentu bagian dari kawasan hutan tersebut keluar surat pemberitahuan pajak terhutang (SPPT). Oleh karena sudah jelas SK-nya, maka yang melakukan klaim itu dianggap sebagai'oknum', ada imingiming sertifikat tanah dari oknum tersebut kepada masyarakat. Sementara itu, Kepala Dinas Kehutanan dan Perkebunan, Abd. Razak membenarkan informasi Asper Rifa'i, bahwa kawasan yang dijadikan sengketa oleh oknum itu di bawah pengelolaan Perum Perhutani karena dari petanya tampak bahwa itu memang milik negara.

Oleh karena hingga saat ini belum ada titik temu, persoalan di kawasan tersebut akan berlarut-larut jika tidak diselesaikan di pengadilan agar tanah tersebut jelas statusnya. Kepala Badan Pertanahan Nasional Bangkalan, melalui Kasi Sengketa, Konflik dan Perkara, juga mengaku bahwa kawasan hutan yang disengketakan oleh masyarakat statusnya milik negara.Terhadap tanah-tanah tersebut hingga saat ini belum ada pengajuan untuk membuat sertifikat tanah.Sehingga, kawasan hutan yang diklaim warga itu sampai saat ini masih dalam pengakuan masyarakat Dusun Bulak, Desa Patengteng.

Apabila dicermati baik konflik maupun penjarahan oleh masyakat terhadap hutan negara salah satunya berakar pada lambatnya pengembangan organisasi pengelolaan hutan di tingkat lapangan (KPH).Salah satu keberadaan KPH dalam mendukung Kabupaten di mana KPH tersebut berada (dalam hal ini Kabupaten Bangkalan) adalah penguatan kelembagaan masyarakat. ${ }^{1}$

1 Kementerian Kehutanan, Social Forestry Menuju Restorasi Pembangunan Kehutanan Berkelanjutan, Pusat Penelitian dan Pengembangan Perubahan Iklim dan Kebijakan, Bogor, 2010, hlm. 64. 


\section{Gambar 1. Peta Wilayah Sengketa Tanah}

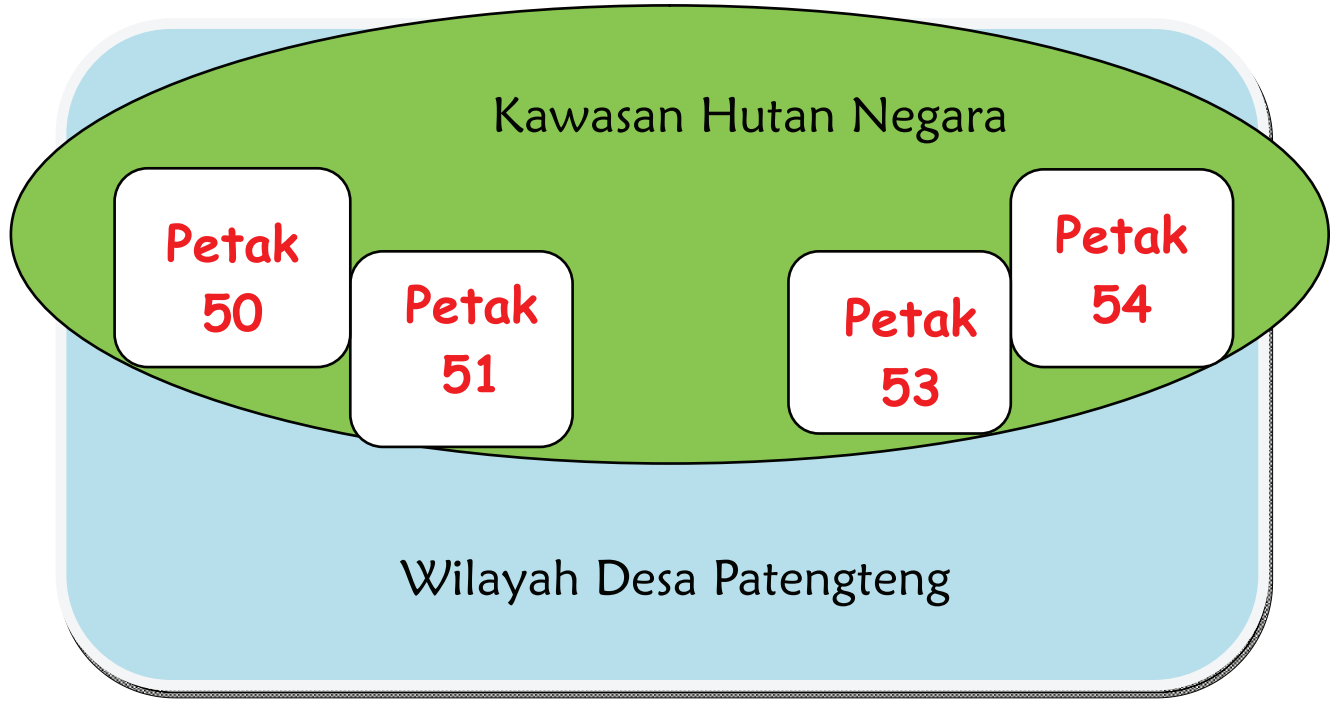

\section{Sumber: Data KPH Madura 2014}

Uraian Gambar:

- Wilayah sengketa tanah ada di kawasan hutan petak 50, 51, 53 dan petak 54, tempat masyarakat mencari nafkah;

- Berdasarkan informasi mitra II (Perhutani): Petak-petak yang disengketakan tersebut adalah Kawasan Hutan Negara yang masuk wilayah administratif desa Patengteng (SK Menteri Kehutanan);

- Masyarakat ada yang memiliki bukti pembayaran pajak (SPPT PBB) atas Persil (petakpetak) tersebut.

Kegiatan tersebut seharusnya terintegrasi dalam reformasi bidang kehutanan yaitu melalui program Pengelolaan Hutan Bersama Masyarakat. Akan tetapi kenyataan di lapangan program tersebut belum seluruhnya menyentuh masyarakat, khususnya pada masyarakat sekitar hutan.Hal tersebut menunjukkan adanya gap antara kebijakan dan pelaksanaan yang mana hal tersebut menimbulkan permasalahan yang cukup serius berupa munculnya konflik-konflik dan berbagai permasalahan yang menyertainya. Baik Perum Perhutani maupun masyarakat dusun Bulak ingin segera ditemukan solusi untuk mengatasi masalah konflik tersebut.

Terjadinya masalah konflik maupun penjarahan hasil hutan yang menjadi wewenang pengelolaan Perum Perhutani KPH Madura di desa Patengteng Kecamatan Modung Kabupaten Bangkalan menunjukkan akibat dari lemahnya Pemerintah dalam menjalankan kewajiban dalam mengamankan asset hutan dan hasil hutan. Keadaan open accsess , memudahkan siapapun memanfaatkannya tanpa kontrol. Kebutuhan akan pengamanan, sosialisasi dan penyuluhan 
pada masyarakat sekitar hutan seharusnya menjadi skala prioritas yang harus segera ditangani.

Atas dasar permasalahan tersebut di atas maka perlu dilakukan penelitian intensif, terperinci dan mendalam. Melalui kegiatan pengabdian ini diharapkan dapat menjadi penghubung antara Pemerintah (Perum Perhutani) dalam menjalankan kegiatan penguatan kelembagaan masyarakat dengan masyarakat sekitar hutan desa Patengteng sebagai kelompok sasaran. Dengan berhasilnya upaya penguatan kelembagaan masyarakat diharapkan berdampak yang lebih besar bagi pelaksanaan tugas Perum Perhutani KPH Madura yaitu pengamanan dan perlindungan hutan serta sebagai institusi penyelesai konflik di tingkat tapak/lapangan.

Lokasi kegiatan pengabdian ini adalah Dusun Bulek Desa Patengteng Kecamatan Modung Kebupaten Bangkalan, tempat terjadinya konflik antara masyarakat sekitar hutan dengan Perum Perhutani KPH Madura.

Disadari bahwa baik konflik maupun penjarahan oleh masyakat terhadap hutan negara salah satunya berakar pada lambatnya pengembangan organisasi pengelolaan hutan di tingkat lapangan (KPH).Salah satu keberadaan KPH dalam mendukung Kabupaten di mana KPH tersebut berada (dalam hal ini Kabupaten Bangkalan) adalah penguatan kelembagaan masyarakat. ${ }^{2}$ Kegiatan tersebut seharusnya terintegrasi dalam reformasi bidang kehutanan yaitu melalui program Pengelolaan Hutan Bersama Masyarakat. Beranjak pada permasalahan di atas maka kegiatan pengabdian ini bertujuan di samping menyelesaikan konflik yang terjadi:

1. Membentuk LMDH di desa Patengteng Kecamatan Modung Kabupaten Bangkalan.

\section{Proposal PHBM.}

3. Mendorong masyarakat untuk mensertifikatkan lahannya.

Langkah awal untuk dapat melakukan kegiatan-kegiatan dalam mencapai tujuan penelitian ini adalah dengan melalui tehnik diskusi kelompok terfokus (Forum Group Discussion $/ F G D)^{3}$ Tehnik ini dilakukan untuk: 1. Menggali pemahaman masyarakat tentang status kawasan hutan yang diklaim oleh masyarakat, yang menjadi wewenang Perum Perhutani KPH Madura;

2. Melakukan "sharing" pentingnya status kemilikan kawasan hutan untuk mencegah potensi konflik, keinginan dan kendala masyarakat yang akan mensertifikatkan tanahnya.

3. Menjembatani komunikasi yang "terputus" antara masyarakat sekitar hutan desa Patengteng Kecamatan Modung Kabupaten Bangkalan dengan pihak Perum Perhutani.

Program pengabdian masyarakat dengan 
kegiatan program ipteks bagi masyarakat sekitar hutan ini dengan rencana sebagai berikut:

1. Sosialisasi pada masyarakat tentang status kawasan hutan yang menjadi wewenang pengelolaan Perum Perhutani KPH Madura;

2. Mendorong dan membantu masyarakat untuk mensertifikatkan Hak atas Tanah miliknya sebagai upaya mencegah potensi konflik dan meyadarkan bahwa menjarah hasil hutan yang menjadi wewenang Perum Perhutani PKH Madura adalah perbuatan kriminal.

3. Mendampingi masyarakat desa Patengteng untuk membentuk LMDH dalam rangka pengelolaan sumber daya hutan dengan sistem PHBM.

4. Mengurus ijin pemanfaatan sebagian kawasan hutan yang menjadi wewenang Perum Perhutani KPH Madura, agar masyarakat dapat meningkat kesejahteraannya.

5. Merumuskan proposal model kemitraan antara masyarakat sekitar hutan desa Patengteng Kecamatan Modung Kabupaten Bangkalan dengan Perum Perhutani KPH Madura;

Peran/ partisipasi masyarakat nampak dalam $F G D$ dan sosialisasi. $F G D$ adalah suatu metode partisipatif dalam pengumpulan informasi mengenai suatu permasalahan tertentu sangat spesifik melalui diskusi kelompok. Partisipasi masyarakat tercermin dari proses diskusi, yang difasilitasi oleh moderator dan peserta sendiri yang mengemukakan permasalahan dan kebutuhannya. ${ }^{4}$ Melalui FGD dan sosialisasi, permasalahan yang telah diidentifikasi dipertajam. Dilanjutkan dengan penentuan target luaran, perencanaan pelaksanaan kegiatan, dan diakhiri dengan penyusunan proposal model kemitraan (PHBM). Diskusi untuk mempersiapkan ijin sementara pengelolaan dan pemanfaatan kawasan hutanyang diajukan ke Perum Perhutani Unit II Jawa Timur KPH Madura.

Dalam kegiatan pengabdian ini akan dipilih 10 (sepuluh) orang yang akan mewakili Mitra I (Masyarakat desa hutan) dan Mitra II (Perum Perhutani) masing-masing 5 (lima) orang yaitu:

- Mewakili mitra I, masyarakat desa sekitar hutan (desa Patengteng):

Abd. Rahman (Kades), Moh. Amin (Sekdes), Ust. Dhofir (Waka BPD), Nisan (Kadus Belet), Akh. Saifudin (tokoh masyarakat)

- Mewakili Mitra II, Perhutani:

Dudi Kurniadi (Kepala KPH Madura), Adang Sukendar (Wk. Ka.KPH Madura), Hartono, Moh. Djiman, Moch. Rifa`i (Asper). 


\section{Pembahasan}

A. Pemetaan Konflik dalam Kerangka Pencarian Solusi yang Menguntungkan bagi Pihak-pihak yang Berkonflik

Berdasarkan rekapitulasi konflik tenurial sampai bulan Juni 2015, KPH Madura Perum Perhutani Divisi Regional Jawa Timur mengidentifikasi ada beberapa jenis konflik yaitu:

1. Mengerjakan kawaan hutan tanpa ijin: terdapat 3 kasus pada 16 petak dengan luas 67, $22 \mathrm{Ha}$.

2. Menggunakan kawasan hutan tanpa ijin: terdapat 6 kasus pada 16 petak dengan luas $335,90 \mathrm{Ha}$.

3. Menduduki kawasan hutan tanpa ijin: terdapat 3 kasus pada 3 kasus dengan luas $58,45 \mathrm{Ha}$.

4. Melakukan aktifitas atau kegiatan penyelidikan umum atau eksplorasi atau eksploitasi bahan tambang di dalam kawasan hutan: terdapat 3 kasus pada 22 petak dengan luas 141,77 Ha.

5. Klaim kepemilikan lahan kawasan hutan: terdapat 1 kasus pada 1 petak denga luas 29,40 Ha.

6. Pensertifikatan lahan kawasan hutan oleh pihak lain: terdapat 1 kasus pada 1 petak dengan luas 10,00 Ha.

7. Masalah yang timbul akibat proses pinjam pakai kawasan hutan yang belum /tidak teselesaikan.

8. Permasalahan batas kawasan dengan pihak lain.
Sementara berdasarkan fakta yang didapatkan di lapangan ternyata di masyarakat yaitu desa Patengteng Kecamatan Modung Kabupaten Bangkalan terbentuk 3 (tiga) kelompok masyarakat:

1. Beberapa orang dipidana sebagai "penjarah" berdasarkan Putusan PN Bangkalan Nomor 229/Pid.Sus/214/PN. Bangkalan dan satu kasus yang masih proses kasasi yang diajukan oleh PU. Berdasarkan pengamatan di persidangan terungkap bahwa beberapa orang yang melakukan penjarahan karena memiliki persepsi bahwa kayu-kayu yang mereka ambil berada dalam kawasan milik mereka. Mereka sejak berpuluh-puluh tahun sudah menggantungkan hidup mereka di sana.

2. Warga masyarakat yang menginginkan kejelasan status tanah mereka, karena mereka merasa tanah mereka adalah warisan nenek moyang yang dengan demikian bukan menjadi wewenang pengelolaan Perum Perhutani KPH Madura. Namun demikian mereka menerima apabila tanah yang menjadi sumber konflik adalah tanah yang termasuk kawasan hutan yang menjadi wewenang Perhutani.

3. Ada "Tokoh" yang terkesan menjadi provokator masyarakat, bahwa tanah mereka bukan termasuk lahan Perhutani dan si "tokoh" ini berada di luar kawasan hutan tetapi berhak atas kawasan tersebut karena warisan. Bukti-bukti 
kepemilikan atas beberapa tanah warga tersebut diserahkan pada si "Tokoh" tersebut dijanjikan untuk disertifikatkan. Berdasarkan informasi dari perangkat kecamatan Modung, ada indikasi bahwa bukti-bukti atas tanah mereka, walaupun bukan Sertifikatyang berkekuatan hukum, sudah ada di tangan si "Tokoh" yang sampai saat ini belum ada kejelasannya.

Apabila dilihat dari perspektif antropologi, menurut Nurjaya, bahwa konflik yang terjadi dalam masyarakat paling tidak dapat dikategorikan menjadi 3 (tiga) macam yaitu: ${ }^{5}$

1. Konflik kepentingan (conflict of interest);

2. Konflik antar nilai (conflict of values);

3. Konflik norma dengan norma (conflict of norms).

Berdasarkan Surat Keputusan Menteri Kehutanan Nomor: 26/Kpts-II/1987 tentang Penetapan Kelompok Hutan Gunung Lombag Daya, Gunung Patengteng Srabi, Gunung Mangaan Sanjangan, Gunung Serengan, Gunung Labuhan, Gunung Lajing, Gunung Kemayoran dan Gunung Sragi di Kabupaten Bangkalan , Seluas 3.137,75 HA sebagai Kawasan Hutan. Di dalamnya terdapat lampiran tentang Berita Acara Tata Batas Hutan disebutkan bahwa berdasarkan Surat Keputusan Gubernur Jawa Timur tgl. 15 April 1979 Nomor 31/1979, nama -nama yang disebutkan dalam Lampiran i sebagai anggota Panitia Tata Batas telah mengadakan rapat dan pemeriksaan setempat untuk menetapkan batas-batas yang tetap dari areal hutan yang akan ditetapkan sebagai kawasan hutan. Dalam Berita Acara Tata Batas tersebut tercantum Edy Hoesono selaku Camat Kepala Wilayah Kecamatan Modung sebagai anggota.

Berdasarkan gambaran tersebut di atas seharusnya saat penentuan tata batas tersebut adalah kesempatan untuk melibatkan masyarakat sekitar hutan untuk berpartisipasi. Sebelum kedatangan penjajah, masyarakat memiliki hak historis atas kawasn hutan tersebut. Pada tahun 1873 Jawatan Kehutanan membentuk organisasi teritorial kehutanan berdasarkan Staatsblad N0. 215-1873 mk kawasan hutan Jawa dibagi menjadi 13 Daerah Hutan. Untuk kepentingan pekerjaan bagian perencaan hutan unit-unit perencanaan yang disebut Bagian Hutan ditentukan luas masing-masing 4000-5000 hektar ${ }^{6}$ Sudah barang tentu pembagian tersebut "bernuansa" penjajah tanpa memperdulikan hak-hak masyarakat sekitar hutan. Dengan hilangnya kesempatan masyarakat untuk berpartisipasi dalam penetuan tata batas tersebut mau tidak mau secara yuridis masyarakat telah hilang hak mereka atas kawasan hutan tersebut. Sebagai konsekuensi apabila memanfaatkan hasil hutan tanpa ijin adalah kejahatan sebagaimana diatur dalam Undang-undang Nomor 41 Tahun 1999 tentang Kehutanan.

5 Dikutip dari Bambang Eko Supriyadi, Hukum Agraria Kehutanan Aspek Hukum Pertanahan dalam Pengelolaan Hutan Negara, RajaGrafindo Persada, Jakarta, 2013, hlm. 170.

6 I Nyoman Nurjaya, Pengelolaan Sumber Daya Alam dalam Perspektif Antropologi Hukum, UM Pers, Malang, 2000, hlm. 120. 
Apabila dicermati Undang-undang Nomor 18 Tahun 2013 tentang Pencegahan dan Pemberantasan Perusakan Hutan terdapat ketentuan dalamPasal 83 ayat(3) bahwa apabila masyarakat sekitar hutan memanfaatkan kayu yang diduga hasil pembalakan liar pelaku di pidana dengan pidana penjara paling singkat 3 (tiga) bulan dan paling lama 2 (dua) tahun dan/atau pidana denda paling sedikit Rp500.000,00 (lima ratus ribu rupiah) dan paling banyak Rp500.000.000,00 (lima ratus juta rupiah). Apabila dibandingkan dengan ketentau yang diatur dalam Undang-undang Nomor 41 Tahun 1999 (UU Kehutanan) jelas lebih ringan yaitu dengan ancaman pidana paling pendek 1 (satu) tahun dan paling lama 5 (tahun). Di samping itu dalam UU Kehutanan tidak membedakan siapa pelakunya.

Berdasarkan rumusan demikian itu maka nampak secara implisit sesungguhnya ada "pengakuan" bahwa masyarakat sekitar hutan seharusnya memiliki hak atas pemanfaatan hasil hutan. Oleh karenanya konflik yang terjadi di beberapa tempat khususnya di desa Modung Kecamatan Modung Kabupaten Bangkalan harus dapat dicapai resolusi konflik.

Beberapa Peneliti menemukan fakta bahwa hak ulayat atas hutan ditiadakan dan praktik adat dianggap sebagai kejahatan oleh pemerintah kolonial di Asia dan Afrika serta negara-negara merdeka di Amerika Latin berdasarkan kebijakan tentang kayu dan alam liar. Untuk Indonesia fakta tersebut diungkap oleh Peluso. $^{7}$

Mencermati konflik-konflik yang terjadi dapat dikaji dengan beberapa pembahasan tentang tatanan tenurial adat yang meliputi hakikat sistem adat (berbagi, tumpang tindih, melekat), kemajemukan hukum, pengesahan hak ulayat dan kewenangan adat). Dengan karakter tatanan tenurial yang demikian ini maka beberapa peneliti berpandangan bahwa sistem tersebut membuatnya kokoh dan fleksibel dan yang sudah barang tentu menjadi kuat dan bertahan menghadapi serta melawan perbedaan pandangan dominan berkaitan dengan tenurial lahan. ${ }^{8}$ Pada satu sisi yang lain tingkat fleksibilitas dalam sistem adat juga perlu dipertanyakan, mengingat bahwa tidak semua orang memenangkan perundingan, karena bisa jadi kelompok yang lebih kuat melanggar hak atas kelompok yang lebih lemah. ${ }^{9}$

Berdasarkan fakta yang ada di lapangan yang mana terdapat 3 (tiga) kelompok membenarkan adanya beberapa hasil penelitian yang menyatakan bahwa proses untuk mencapai pengesahan atas kepemilkan lahan dapat meningkatkan persaingan, memancing sengketa dan bukannya menguranginya. Dengan kata lain apabila

7 Nancy Lee Peluso, Forest-Based Cultures of Resistance, University of California Press, Berkeley, CA, AS., 1992, hlm. 12-24.

8 Sara Berry, No-Condition is Permanent - The Social Dynamics of Agrarian Change in Sub-Saharan Africa, Madison, University of Wisconsin Press, WI, AS, 1993, hlm. 34.

9 Peter Berger, Peter. L and Thomas Luckman, The Social Construction of Reality A Treatise in The Sociology of Knowledge, Penguin Books Lmt, Harmonsworth, Middlesex, England, 1996, hlm. 204. 
klaim didasarkan pada sistem adat maka masyarakat berusaha membuktikan haknya melalui para leluhur mereka yang bergantung pada apa yang dianggap dapat meningkatkan legitimasi pengakuan. ${ }^{10}$

Melihat adanya konflik tersebut di atas kiranya relevan apabila dilakukan analisis. Tujuan utamanya adalah agar bisa dikembangkan analisis yang nantinya akan mendukung program penanganan konflik, baik pengelolaan maupun resolusi konflik. Untuk dapat melakukan analisis terhadap konflik yang terjadi maka sudah barang tentu harus dipahami apa pengertian yang sesungguhnya dari dari konflik serta unsur-unsur konflik.

Webster menyatakan bahwa "konflik berarti persepsi mengenai perbedaan kepentingan (perceived divergence of interest), atau suatu kepercayaan bahwa aspirasi pihak-pihak yang berkonflik tidak didapat dicapai secara simultan". ${ }^{11}$ Sedangkan unsur dari konflik adalah persepsi, aspirasi dan pihak-pihak yang terkibat di dalam konflik itu sendiri. Oxford Advance Leaner`s Dictionary (1989) membagi persepsi ke dalam 3 (tiga) arti yaitu kemampuan untuk melihat atau memahami sesuatu, kualitas pemahaman dan yang ketiga suatu cara memahami sesuatu. Dengan demikian persepsi secara umum dapat diartikan sebagai bagaimana seseorang atau sekelompok orang memahami sesuatu menurut cara dan pengertian mereka. ${ }^{12}$ Jadi memiliki makna subyektif. Sedangkan persepsi dalam pengertian sosial mengacu pada teori konstruksi sosial yang dikembangkan oleh Peter L Berger dan Thommas Luckman ${ }^{13}$ (1991). Teori tersebut memandang manusia pada dasarnya mempunyai 2 (dua) realitas ganda yaitu realitas obyektif dan realitas subyektif. Dengan demikian seseorang dalam menjalin interaksi dengan orang lain dilandasi oleh 2 (dua) realitas tersebut.

Unsur kedua dari konflik adalah aspirasi. Aspirasi diartikan sebagai keinginan yang kuat sehingga dalam mencapainya harus diperjuangkan. Harus diperjuangkan dalam mencapai aspirasi tersebut karena aspirasi itu sendiri mengisyaratkan adanya kepentingan dan kebutuhan. Setiap individu, kelompok sosial, organisasi swasta maupun negara mempunyai angka kepentingan yang berbeda dalam tingakatannya masing-masing. Hubungan antara kepentingan dan kebutuhan diibaratkan seperti hubungan lapisan atom. Kepentingan merupakan inti yang tidak dapat dikompromikan sedangkan kebutuhan bisa menemukan berbagai variasi atau pilihan dan bersifat bisa dinegosiasikan.

Unsur ketiga darikonflik adalah aktor, aktor ini merupakan inti yang akan menciptakan bentuk-bentuk konflik dan dinamikannya. Aktor dalam konflik ini dapat dibedakan

10 Sara Berry, Op.cit., hlm. 41.

11 Novri Susan dan Ucu Martanto, Resolusi Konflik, dalam Bahan Diklat Pengembangan Kapasitas Sumber Daya Manusia Kepala Desa dalam Tata Pemerintahan Desa yang Baik, CSWS-Unair, 2015, hlm. 113.

12 Ibid.

13 Peter. L. Berger and Thomas Luckman, Op.cit., hlm. 204. 
yaitu aktor dengan kepentingan diri dan kelompoknya dan aktor dengan kepentingan membantu menyelesaikan konflik. Dalam konflik yang terjadi antara masyarakat sekitar hutan dengan Perum Perhutani sebagai pihak yang mewakili negara maka perlu ditempuh resolusi konflik yang Fisher menyebut sebagai Interactive Conflict Resolustion (ICR). ICR menekankan pendekatan psikologisosial yang memiliki tujuan utama adalah pemahaman yang mendalam, pengakuan dan saling menghormati, solusi dapat diterima bersama-sama dan berkelanjutan. ${ }^{14}$

Konflik merupakan fenomena sosial yang kompleks, maka setiap usaha untuk menanganinya membutuhkan langkahlangkah persiapan yang terencana secara baik dan cermat. Dalam konteks ini, setiap orang yang bekerja dan aktif dalam penaganan konflik haruslah berusaha untuk memperoleh pemahaman yang lebih baik mengenai dinamika, hubungan dan issuissu terkait dengan situasi (konflik) yang bisa membantu mereka untuk merencanakan strategi dan melakukan tindakan yang lebih baik. Langkah ini merupakan langkah penting dan strategis yang berada pada urutan pertama dalam proses penanganan konflik . Artinya bahwa keberhasilan pada langkah ini akan merupakan langkah strategis untuk mencapai kesuksesan pada langkah selanjutnya, yakni penyusunan strategi dan pelaksanakan tindakan penanganan konflik secara tepat. Sebaliknya, kegagalan pada langkah ini, akan berakibat pada kegagalan langkah selanjutnya. Pemahaman yang keliru terhadap suatu konflik, akan berakibat pada penyusunan strategi dan pengambilan tindakan dalam penaganan konflik yang kurang atau bahkan tidak tepat sasaran. Akibatnya bisa fatal, bukannya konflik itu tertangani tetapi justru malah makin membesar.

Untuk dapat menyelesaikan konflik sudah barang tentu harus dilakukan analisa konflik. Menurut Simon Fisher yang dikutip oleh Tolkhah, analisis konflik memiliki manfaat adalah sebagai berikut: ${ }^{15}$

1. Untuk memahami situasi konflik secara lebih baik. Dengan menghadirkan hal-hal yang terkait dengan konflik, seperti para pihak yang terlibat dalam konflik (baik pihak utama maupun pihak di lingkar berikutnya (termasuk pihak ketiga yang berusaha menangani konflik), bagaimana relasi antara para pihak tersebut, apa yang menjadi issu yang dikonflikkan, mana atau siapa dari para pihak itu yang memiliki potensi lebih besar untuk menyelesaikan konflik dan sebagainya.

2. Untuk melihat dengan lebih jelas hubungan antara para pihak yang terlibat atau terkait, baik langsung maupun tidak langsung dalam konflik, bahkan di mana posisi kita (pihak ketiga) yang berusaha

14 Roland J. Fiser, Interactive Conflict Resolution, Syracuse University Press, Syracuse, New York, 1999, hlm. 241.

15 Tolkhah, Pemetaan Konflik (Conflict Mapping), http://wmc-iainws.com/artikel/15-pemetaan-konflikconflict-mapping, diakses 26 Agustus 2015 pukul 09.40 WIB. 
untuk melakukan mediasi berada, dll. Karena keadaan dan sifat hubungan antara para pihak yang terlibat dalam konflik itu beragam, maka pembacaan terhadap hubungan tersebut akan mudah ditangkap dan diingat.

3. Untuk mengklarifikasi dimana kekuatan (utama) itu terletak. Maksudnya, dengan terpetakannya para pihak dan hubungan antara mereka dalam peta konflik, maka secara mudah pula diketahui kekuatan masing-masing pihak di dalam mempengaruhi (baik positif maupun negatif) terhadap keadaan dan perkembangan konflik.

4. Untuk mengecek sendiri keseimbangan aktifitas atau kontak seseorang. Melalui peta konflik yang menghadirkan juga bagaimana hubungan antara para pihak yang terlibat dalam konflik, maka frekuensi dan intensitas komunikasi dan aktivitas antar para pihak (termasuk pihak ketiga yang menangani konflik) dapat dipantau. Hal ini akan membantu juga bagi pihak ketiga untuk menemukan celah dan jalur yang dapat dilalui dan digunakan secara tepat untuk memaksimalkan usaha pengambilan tindakan dalam penangan konflik dari sudut lalu lintas hubungan antar para pihak yang berkonflik tersebut.

5. Untuk melihat dimana sekutu atau aliansi atau sekutu potensial berada. Tergambarkannya bagaimana sifat dan keadaan hubungan antar para pihak yang terlibat dalam konflik, secara otomatis akan mempermudah pemetakan para pihak dalam kelompok-kelompok atau kategori-kategori tertentu, misalnya mana sekutu dan mana lawan dari para pihak yang terlibat dalam konflik.

6. Untuk mengidentifikasi pembukaan untuk intervensi atau pengambilan tindakan. Kapan waktu untuk melakukan intervensi dan darimana intervensi itu dilakukan juga akan dapat diketahui dengan lebih simple melaui peta konflik ini.

7. Untuk mengevaluasi apa yang telah dilakukan. Segala hal yang telah dilakukan oleh pihak yang menangani konflik menyangkut konflik yang ditanganinya juga akan terpantau lewat simbol yang diberikan dalam peta konflik. Dengan demikian evaluasinya juga dapat dilakukan dengan tepat.

Untuk menyelesaikan konflik yang terjadi, dapat merujuk pada panduan pemetaan konflik yang dirumuskan oleh Miall, yaitu untuk melihat pihak-pihak yang bertikai dan persoalannya: ${ }^{16}$

1. Siapa yang menjadi inti pihak bertikai?

Dalam kasus konflik di desa Patengteng ini yang menjadi inti ada 4 (empat) kelompok:

a. Klaim kepemilikan lahan kawasan hutan oleh beberapa warga yang hidup di sekitar hutan yang berdekatan dengan 
kawasan hutan yang dikelola oleh Perum Perhutani;

b. Persorangan yang mengambil hasil hutan tanpa ijin, yang didasari pemahaman bahwa lahan yang "dijarah" adalah warisan nenek moyang;

c. Pihak perseorangan yang memanfaatkan kondisi ketidakpastian (menurut persepsi yang bersangkutan);

d. Perum Perhutani KPH Madura yang mewakili negara dalam pengelolaan sumber daya hutan.

e. Kepala Desa sebagai aktor konstruktif, yaitu pihak yang seyogyanya mampu melakukan mediasi (penengah) konflik dan pengambil kebijakan tegas.

2. Apa persoalan konflik?

Persoalan konflik adalah adanya persepsi dari masyarakat sekitar hutan di desa Patengteng yang mengklaim bahwa lahan yang dikelola Perhutani adalah lahan mereka. Posisi masyarakat berjuang demi kepentingan mereka sendiri sementara Perum Perhutani mewakili negara sebagai pihak kedua. Aspirasi yaitu keinginan kuat yang harus sama-sama diperjuangkan baik oleh Masyarakat dan Perhutani yaitu tentang klaim kepemilikan lahan, tidak bisa dipisahkan antara kepentingan dan kebutuhan. Artinya apabila kepentingan mereka tentang status kepemilikan tanah diakui maka kebutuhan akan legalitas tidak dapat dinegosiasikan, artinya menjadi suatu keharusan adanya pengakuan yang sah.
3. Apa hubungan pihak-pihak yang bertikai? Hubungan pihak-pihak sudah barang tentu ada ketidaksimetrisan secara kualitatif. Perum Perhutani sebagai pihak yang mewakili negara dalam pengelolaan sumberdaya di tingkat tapak/lapang. Negara sebagai penentu kebijakan pengelolaan di bidang sumber daya hutan.

\section{Apa persepsi penyebab konflik?}

Klaim kepemilikan lahan sebagai persepsi penyebab konflik. Sedangkan sifat konflik adalah vertikal.

5. Apakah perilaku akhir-akhir ini pihak yang bertikai?

Konflik dalam tahap eskalasi. Kegiatan apapun baik yang dilakukan oleh Perum Perhutani maupun Tim Pengusul kegiatan pengabdian, pada awalnya selalu dihadapi dengan sikap curiga dan resistent.

6. Siapa pemimpin pihak-pihak yang bertikai?

Pada tingkat elit dan individual, apa tujuan, kebijakan, kepentingan, kekuatan dan kelemahan relatif mereka?

Pada tingkat individual. Dalam hal ini adalah seseorang yang sudah pernah menjalani pidana karena menjual beberapa kubik kayu di dalam kawasan hutan yang dikelola oleh Perum Perhutani. Di sisi lain ada si "Tokoh" yang memprovokator masyarakat sekitar hutan bahwa mereka berhak atas kawasan hutan tersebut. Kelemahan dari masyarakat mereka hanya memiliki hak kepemilikan adat yang diindikasikan sudah diserahkan 
pada si "Tokoh" untuk dibantu melakukan pensertifikatan lahan mereka.

Pada tingkat elit, secara individual tidak ada, secara kelembagaan Perum Perhutani yang diwakili oleh Kepala KPH Madura bertujuan dan memiliki kepentingan untuk "menyelamatkan" tanah negara. Kebijakan yang akan ditempuh adalah melaksanakan program PHBM yang diusulkan oleh Tim dan pembentukan LMDH. Kelemahan Perum Perhutani KPH Madura, dalam skala nasional, luasnya hutan yang tidak dikelola menjadi penyebab lemahnya pemerintah menjalankan kewajiban dalam mengamankan asset hutan alam maupun hasil rehabilitasi.

Ada beberapa konsep tata pengelolaan dan resolusi konflik yaitu:

- Tata Keamanan yaitu proses memelihara/ menciptakan keamanan oleh aparatur negara dan masyarakat. Negara berwenang menggunakan kekerasan positif berbasis peraturan dan aspirasi publik.

- Tata Resolusi konflik yang mana dalam proses ini melibatkan aktor-aktor berkonflik ke dalam tata kelembagaan penyelesaian konflik tanpa kekerasan baik melalui prosedur hukum (judisial) atau non-judicial yang dikenal dengan sebutan resolusi konflik alternatif. ${ }^{17}$

\section{B. Alasan Pembentukan Lembaga Masyarakat Desa Hutan di Desa Patengteng Kecamatan Modung Kabupaten Bangkalan.}

Berdasarkan pemetaan konflik di atas maka Kepala Desa Patengteng seharus mampu membawa para aktor ke dalam proses tata kelembagaan penyelesaian konflik tanpa kekerasan baik melalui prosedur hukum (judisial) atau non-judicial. Prosedur hukum harus ditempuh dalam hal menetapkan status maupun batas kawasan yang jelas mana yang merupakan milik warga maupun kawasan hutan milik negara. Sedangkan prosedur non-judicial juga dapat ditempuh melalui pembentukan Lembaga Desa Hutan (LMDH) di desa Patengteng.

Realitas di atas menunjukkan bahwa untuk mencapai tujuan pengelolaan hutan, baik mempertahankan hutan alam yang tersisa maupun membangun hutan tanaman baru dan diharapkan berhasil, diperlukan prioritas kegiatan teknis sekurang-kurangnya mencakup:

1. Penyelesaian masalah kawasan hutan yang telah terjadi dan menghindari terjadinya masalah baru di masa depan serta meningkatkan kapasitas pengelolaan hutan konservasi dan hutan lindung. 
2. Mempermudah akses bagi penerima manfaat atau dapat menekan terjadinya ekonomi biaya tinggi serta terdapat landasan kuat untuk mengalokasikan manfaat hutan secara adil.

3. Menyediakan infrastruktur sosial maupun ekonomi bagi penguatan kelembagaan lokal terutama yang mendapat akses pemanfaatan sumberdaya hutan, peningkatan efisiensi ekonomi maupun pengembangan nilai tambah hasil hutan.

Pembentukan LMDH yang akan dilaksanakan dilatarbelakangi oleh sebuah tuntutan realitas bahwa Desa Patengteng merupakan salah satu desa di Kecamatan Modung yang secara geografis merupakan desa pemangku hutan. Sementara dilihat dari aspek sosial, budaya dan ekonomi, mayoritas masyarakat setempat mempunyai aktivitas ekonomi dengan menggantungkan pada pemanfaatan hasil hutan yang berdekatan dengan kawasan hutan menjadi wilayah pangkuan KPH Madura Barat. Sudah barang tentu aktivitas ekonomi tersebut memiliki risiko yang sangat tinggi terhadap kelangsungan kelestarian hutan itu sendiri. Hal itu terbukti dengan tingginya tingkat pencurian kayu hutan oleh oknum warga. Pembentukan LMDH ini sebagai komponen penting dalam pelaksanaan program PHBM.

LMDH desa Patengteng sebagai forum komunikasi masyarakat maka diharapkan memiliki fungsi antara lain:

1. Pengayom dan pelindung masyarakat desa hutan Patengteng;.
2. Menampung, mengelola dan menyalurkan aspirasi warga desa hutan;

3. Mitra yang kerja atau usaha yang aktif dan kritis bagi Perum Perhutani KPH Madura dalam rangka pola kemitraan pengelola hutan.

4. Pelopor dalam meningkatkan mutu sumber daya manusia dan hutan pada umumnya dan anggota pada khususnya dalam rangka pola kemitraan pengelola hutan.

LMDH dibentuk untuk melakukan pengelolaan hutan dalam sistem Pengelolaan Sumberdaya Hutan Bersama Masyarakat (PHBM) yang mencakup aspek: a) penguatan dan pengembangan lembaga, b) perencanaan partisipatif petak hutan pangkuan desa, c) kriteria dan indikator keberlanjutan sumberdaya hutan, dan d) monitoring dan evaluasi.

SK Direksi Perhutani No. 682/KPTS/ Dir/2009 tanggal 31 Desember 2009 tentang Pedoman Pengelolaan Sumberdaya Hutan Bersama Masyarakat merupakan dasar hukum program Pengelolaan Sumberdaya Hutan Bersama Masyarakat (PHBM) dan dilandasi oleh prinsip berbagi peran dan tanggung jawab serta hak dengan Masyarakat Desa Hutan (MDH) dan pihak-pihak yang berkepentingan (Stakeholders) secara proporsional dalam pengelolaan sumber daya hutan. Melalui program PHBM Perhutani sebagai institusi di tingkat tapak melalukan pengembagan perlindungan social, kegiatan peningkatan kegiatan usaha kolaboratif dengan LMDH, 
penyaluran dana CSR, pembangna jaringa kerjasam antara individu, kelompok swadaya masyarakat, lembaga pemerintahan, BUMD/ Swasta. ${ }^{18}$

Pengelolaan sumber daya hutan oleh LMDH melalui program PHBM maka langkah awal yang harus ditempuh adalah pendampingan masyarakat. Pendampingan adalah penyadaran akan hak dan kewajibannya, jika masyarakat mulai sadar dan tergerak untuk berupaya bersama-sama, maka mereka membutuhkan pendampingan, sekaligus fasilitasi untuk mengetahui potensi dan kendala yang ada pada mereka dan lingkungan sekitarnya. Upaya pendampingan dan fasilitasi pemahaman potensi dan kendala (analisa peluang, ancaman, hambatan dan tantangan) harus mampu membawa masyarakat yang didampingi tetap selalu termotivasi dan tetap konsisten.

Keberhasilan kegiatan PHBM akan ditentukan oleh aktivitas pendampingan $\mathrm{MDH} / \mathrm{LMDH}$ yang merupakan totalitas kerja baik dari tataran Manajemen KPH yaitu Administratur/Kepala Kesatuan Pemangkuan Hutan (KKPH), Kepala Sub Seksi (KSS) PHBM, Asper/Kepala Bagian Kesatuan
Pemangkuan Hutan (KBKPH), Kepala Resort Pemangkuan Hutan (KRPH), dan terutama pada level Tenaga Pendamping Masyarakat (TPM) atau Fasilitator PHBM.

\section{Simpulan}

Berdasarkan hasil analisis terhadap berbagai kegiatan tersebut di atas maka dapat disimpulkan bahwa:

Konflik yang terjadi di desa Patengteng Kecamatan Modung Kabupaten Bangkalan berlarut-larut tanpa ada kejelasan dan penyelesaian. Pada saat artikel ini dibuat masih ada kesan ketidakpercayaan masyarakat terhadap keberadaan tim pengusul. Sikap masyarakat maupun perangkat desa terpecah antara yang percaya dan resistant. Apa yang terjadi di desa Patengteng Kecamatan Modung Kabupaten Bangkalan hanyalah 1 (satu) dari sekian banyak konflik yang terjadi di Madura. Perangkat desa belum mampu membawa pihak-pihak yang berkonflik ke dalam tata kelembagaan penyelesaian konflik tanpa kekerasan. Padahal kepala desa atau peragkat desa yang lain dengan kewenangannya diharapkan mampu untuk menjadi negosiator bagi warganya. 


\section{DAFTAR RUJUKAN}

Buku

Berry, Sara, 1993, No-Condition is Permanent - The Social Dynamics of Agrarian Change in Sub-Saharan Africa, University of Wisconsin Press, WI Madison.

Berger, Peter. L and Thomas Luckman, 1991, The Socila Construction of Reality A Treatise in The Sociology of Knowledge, Penguin Books Lmt, Harmonsworth, Middlesex, England.

Bambang Eko Supriyadi, 2013, Hukum Agraria Kehutanan Aspek Hukum Pertanahan dalam Pengelolaan Hutan Negara, RajaGrafindo Persada, Jakarta.

CSWS- Unair, 2015, Bahan Diklat Pengembangan Kapasitas Sumber Daya Manusia Kepaa Desa dalam Tata Pemerintahan Desa yang Baik.

Data Perum Perhutani KPH Madura, 2012, Wujudkan PHBM dan Optimalisasi Asset dengan Kebersamaan.

Fisher, Roland J., 2001, Interactive Conflict

Resolution, Syracuse University Press, Syracuse, New York.

Miall dkk, 2002, Resolusi Damai Konflik Menyelesaikan, Mencegah, Mengelola dan Menyelesaikan Konflik Bersumber Politik,Sosial, Agama dan Sara, RajaGrafindo Persada, Jakarta.
I Nyoman Nurjaya, 2000, Pengelolaan Sumber Daya Alam dalam Perspektif Antropologi Hukum, UM Pers, Malang.

Peters, P., 2004, Inequality an Social Cobflict Over Land in Africa, Journal of Agrarian Change 4: 269-314.

Peluso, Nancy Lee, 1992, Forest-Based Cultures of Resistance, University of California Press, Berkeley, CA, AS.

Wahyudi, Isa, 2006, Metodologi Perencanaan Partisipatif, YAPPIKA, Malang.

Kementerian Kehutanan, 2010, Social Forestry Menuju Restorasi Pembangunan Kehutanan

Berkelanjutan, Pusat Penelitian dan Pengembangan Perubahan Iklim dan Kebijakan, Bogor.

\section{Naskah Internet}

Perum Perhutani, Program Pengelolaan Hutan Bersama Masyarakat (PHBM), http://bumn.go.id/perhutani/ halaman/159 tgl. 28 Juni 2015.

Mubarak, "Pemberdayaan Masyarakat Desa Hutan dalam Pengelolaan Hutan Bersama Masyarajat (Perspektif Komunikasi Sosial)", http://pusdikbangsdmperhutani.com/ berita.detail.php?id=175.

Tolkhah, Pemetaan Konflik (Conflict Mapping), http://wmc-iainws.com/ artikel/15-pemetaan-konflik-conflictmapping. 